\title{
Rice Bakanae Disease: Yield Loss and Management Issues in Bangladesh
}

\author{
Latif MA ${ }^{1}$, Uddin $M^{2}{ }^{2}$, Rashid $M M^{1}$, Hossain $M^{1}$, Akter $S^{1}$, Jahan QSA $^{1}$, Hossain $M S^{3, *}$, Ali MA ${ }^{1}$, \\ Hossain MA \\ ${ }^{1}$ Plant Pathology Division, Bangladesh Rice Research Institute (BRRI), Gazipur, Bangladesh \\ ${ }^{2}$ Bangladesh Agricultural University, Mymensingh, Bangladesh \\ ${ }^{3}$ Training Division, Bangladesh Rice Research Institute (BRRI), Gazipur, Bangladesh
}

Received December 30, 2020; Revised April 6, 2021; Accepted April 18, 2021

\section{Cite This Paper in the following Citation Styles}

(a): [1] Latif MA, Uddin MB, Rashid MM, Hossain M, Akter S, Jahan QSA, Hossain MS, Ali MA, Hossain MA , "Rice Bakanae Disease: Yield Loss and Management Issues in Bangladesh," Food Science and Technology, Vol. 9, No. 1, pp. 7 - 16, 2021. DOI: 10.13189/fst.2021.090102.

(b): Latif MA, Uddin MB, Rashid MM, Hossain M, Akter S, Jahan QSA, Hossain MS, Ali MA, Hossain MA (2021). Rice Bakanae Disease: Yield Loss and Management Issues in Bangladesh. Food Science and Technology, 9(1), 7 - 16. DOI: 10.13189/fst.2021.090102.

Copyright $\bigcirc 2021$ by authors, all rights reserved. Authors agree that this article remains permanently open access under the terms of the Creative Commons Attribution License 4.0 International License

\begin{abstract}
Fusarium moniliforme, a causal agent of rice Bakanae is a seedborne fungal disease which infects plants through the roots or crowns and it then grows systemically within the plant. From the in-vitro and in-vivo results, it was concluded that Bavistin, Knowin, Haydazim, Topsil plus and Sunphanate @ 0.3\% could be effective as seed treating fungicides against bakanae disease. Overnight root dipping of seedlings with Bavistin and Knowin@ 0.3\% was effective to control bakanae disease. Seed and seedling treatments with carbendazim fungicides could be used for further dissemination. In field trials, none of the fungicides namely Bavistin, Knowin, Ridomil, Forastin, Sunphanate and Cupravit @ $0.3 \%$ were effective against bakanae compared to rogueing when those were sprayed in the standing crop at tillering stage. In seedbed condition, wet seed bed reduced the $\%$ of bakanae infected hill $(0.31 \%)$ in comparison with semi dry (2.18\%) and dry (3.45\%). In combination with seed bed conditions and seed treatments, wet seed bed with healthy or infected seed but treated with homai@ @ $0.3 \%$ reduced the bakanae incidence $(0.21-0.39 \%)$. Semi dry seed bed with healthy or infected seed but treated with homai @ $0.3 \%$ also control the bakanae disease (0.32-2.68\%) compared to dry seed bed $(0.82-2.7 \%)$.
\end{abstract}

Keywords Rice, Bakanae Disease, Yield Loss, Management

\section{Introduction}

Bakanae (Fusarium moniliforme) is widely distributed in all the rice growing areas especially in Asian countries and it was first reported in 1953 in Bangladesh. This disease is one of the important and uprising devastating diseases in Bangladesh. This disease is common in rice seedbeds and transplanted fields [1,2]. The causal organism of this disease is seed borne, soil borne and also air borne. However, the infected seed plays an important role in disease development [3]. This disease is mostly observed in Kharif season and now-a-days also observed in the Robi season. Bakanae infected rice plants are abnormally tall in height with pale green, thin leaves with few tillers, contain root in the upper nodes, and produce only partially filled or empty grains. The Bakanae disease occurs most frequently when infested seeds (i.e., seeds covered in fungal spores) are used, but also can transmit when the pathogen is present on plant material or in the soil [4-6]. It can spread through water or wind which carries the fungal spores from one plant to another. It can also be transmitted during farm practices such as during, harvesting infected seeds allowing fungal spores to spread to the healthy seeds, and soaking seeds in fungal contaminated water. Bakanae infected seedlings contain lesions on roots, and can die before transplanting or immediately after emergence. Infected rice plants are much taller than normal rice plants. They are also thin, with pale 
green or yellowish green leaves. Roots grow from above-ground nodes on the stem of the infected plant. However, not all infected plants exhibit the visible bakanae symptoms, sometimes they may be stunted or appear normal. Early infection may cause seedlings to die at early tillering stage. Later infection results in plants that develop few tillers having dry leaves [7]. If the rice plants survive to maturity stage, they develop partially filled grains, sterile, or empty grains.

This disease has been responsible for yield losses of up to $50 \%$ [8]. Ito and Kimura [9] reported up to $20 \%$ loss in Hokkaido and as many as $40-50 \%$ losses in the Kinki-chugoku region of Japan. Pavgi and Singh [10] reported the $15 \%$ loss of yield that occurred in eastern districts of Utter Pradesh. Kanjanasoon [11] found $3.7-14.7 \%$ losses in Northern and central Thailand. In the report of BRRI [12], 30\% and 22.29\% yield loss occurred in rice varieties BRRI dhan 29 and BR1, respectively due to this disease especially in Habiganj, Bangladesh. Also some yield loss is estimated due to bakanae disease of rice in the Northern part of the country. This disease caused 3.7-70\% yield reduction in different countries as reported by Lee et al. [13]. However, observations by Talukdar [14], Miah and Zaman [15] confirmed it's occurrence in this country. Although the disease is widely distributed all over the country, significant yield loss was observed in the Southern part of the country. Also some yield loss is estimated due to bakanae disease of rice in the Northern part of the country. Recently, Hossain et al. [16] reported the yield loss about 37.6 to $51.53 \%$ during T. Aus (pre-rainy season) nd T. Aman (rainy) seasons, respectively due to bakanae disease in a naturally bakanae infected fields at Habiganj district of Bangladesh. Relationship between bakanae disease and yield loss indicates that each increase in the disease incidence resulted in a simultaneous reduction in yield. They also found that at lowest (3\%) disease incidence the loss in yield was $1.32 \%$ and also reported the highest disease incidence as high as $22.64 \%$ in Aus season. However, these are the preliminary observations in Bangladesh. Furthermore, it is reported that bakanae disease incidence is more in upland nurseries (dry seed bed) than that of wet seed bed [17], [12]. Studies were carried out showing the effect of management option of bakanae disease by using fungicides in Bangladesh.

\section{Materials and Methods}

The experiments were conducted at Gazipur, Hobigonj (Bakanae disease prone area) and Cumilla districts of Bangladesh which is comprised of Dhaka, Sylhet and Chittagong Divisions, respectively (Figure 1).

\subsection{Detection of Different Fungi on Bakanae Infected Seeds}

In order to determine the seed health status, Blotter method of seed health testing [18] was used to detect the seed borne pathogens associated with it. In this method, three layers of blotter (Whatman no. 1 filter paper) soaked in sterile water were placed at the bottom of a plastic petridish. Petridish, thereafter, 25 seeds for each treatment were placed on wet filter paper. Thus 200 seeds randomly taken from each $500 \mathrm{gm}$ seeds sample were plated in eight replications. The petridishes containing seeds were then incubated at $20 \pm 2^{\circ} \mathrm{C}$ under alternating cycles of $12 \mathrm{hrs}$ Near Ultra Violet (NUV) light and darkness for 7 days. After incubation the seeds were examined in order to record the seed-born fungi that grew out of the seeds. For proper identification of the fungi temporary slides were also prepared and observed under compound microscope.

\subsection{Management of Bakanae Disease through Seed Treatments}

\subsubsection{Effect of Seed Treatments on the Incidence of} Fusarium moniliformae in vitro:

A total of 21 fungicides were evaluated by seed treatment. Seeds were kept in fungicidal suspension @ 0.3\% for overnight. Bakanae infected (12-15\%) rice seeds of BR16 were used for this experiment. Occurrence of seed-borne fungi associated with the seeds was determined by the modified blotter methods [18]. Two hundred seeds were randomly picked from each sample and plated on three layers of well moistened 9 -cm filter paper in plastic petri-dishes and incubated at $25 \pm 1^{\circ} \mathrm{C}$ alternating with 12 hrs of Near Ultra Violet (NUV) light and 12 hours of darkness. After 7 and 15 days of incubation the fungi were identified by the growth characters.

\subsubsection{Effect of Seed Treatments on the Incidence of} Bakanae Disease in Seedbed Condition

Out of 21 fungicides, a total of 12 fungicides were tested against bakanae disease of rice. Bakanae infected seeds (12-15\% incidence) of BR16 were collected from Cumilla. Two hundred grams $(200 \mathrm{~g})$ of seeds were kept in each fungicidal suspension @ $0.3 \%$ for overnight. After treatment, the seeds were sown in seedbed and incidence of disease was observed. The experiment was conducted in Randomized Complete Block (RCB) design with three replications.

\subsection{Management of Bakanae Disease through Root Dipping of Rice Seedling by Fungicides}

In total 4 farmers were selected from Jagotpur and Dariapur, Sadar Upazila, Habigonj to validate root dipping of seedling in fungicidal suspension for the control of bakanae disease (Figure 1). Three fungicides namely Bavistin, Knowin and Ridomil MZ @ 0.3\% (0.3g in $100 \mathrm{ml}$ water) were used in this experiment. Before transplanting, roots of 30-days old bakanae infected seedlings were dipped in three fungicidal suspensions for overnight. 
Rogueing of infected seedling or tiller was done at seedbed and main field. A control treatment (Without root dipping and rogueing) was maintained. Plot size for each treatment was $100 \mathrm{sqm}$. Same treatments were assigned in four farmers' field. Each farmer's field considered as a replication and followed Randomized Complete Block (RCB).

\subsection{Management of Bakanae Disease at Field Condition by Fungicides}

The experiments were conducted in three farmers' fields at Jagotpur, Habigonj during T.Aus season, 2007 to find out suitable fungicides for the management of bakanae disease. In each farmers field two fungicides were applied. Six fungicides namely, Bavistin, Knowin, Ridomil, Forastin, Sunphanate and Cupravit@ 0.3\% were used. Unit plot size was $20 \mathrm{~m} \mathrm{X} 20 \mathrm{~m}$. RCB design with three replications was followed. The variety used in these experiments was BR1. The fungicides were sprayed at 25 DAT (Days after transplanting) after roguing of bakanae infected tiller. Rogueing of infected tiller at 25DAT and no roguing of infected tiller (Control) were also maintained as treatments in this experiment.

\subsection{Effect of Seed Bed Condition and Fungicides for the Control of Bakanae Disease}

Experiments were conducted in two consecutive seasons at the research field of BRRI (Bangladesh Rice Research Institute) regional station Cumilla (Figure 1). The land was medium high. The soil is silty-loam with $\mathrm{pH}$ value of 5.0-5.7 and organic matter content is $1.8-2.0 \%$. A high yielding but Bakanae susceptible cultivar BR22 was selected for the study. Treatments were as follows:

Factor A (Main plot) seed condition
a) Infected seed (non-treated);
b)= Infected seed but treated with Homai @ 0.3\%;
c) = Healthy seed;

Factor B (Sub plot) seed bed condition

a) Dry seed bed (D);

b) Semi dry seed bed (SD);

c) Wet seed bed (W)

The experiment was laid out in 2 factors Split Plot Design with three replications. The experimental area for each replication was first divided into three plots where three treatments were allocated randomly considered as main plot. Each of main plots divided into 3 and 3 treatments allocated randomly which was considered as sub plot. The area of unit plot was $12 \mathrm{~m}^{2}(4.0 \mathrm{~m} \times 3.0 \mathrm{~m})$. The space between the blocks and plot was 1.0 and $0.5 \mathrm{~m}$, respectively. Seeds were treated with Homai @ 0.3\% (w/v) under thiophanate methyl group for overnight.
Seed bed preparation and seed sowing: Three types of seed bed were prepared by puddling the soil. Two seed beds were in high land and one in low land. Each type of seed bed received a) infected seed but non-treated, b) infected seed but treated with homai @ 0.3\%,c) healthy seeds. In two high land seedbeds, one was not allowed standing water and therefore seed bed become cracked called dry (D) and the other was dried but before uprooting the seedlings, seedbed was allowed water for 5 days for softening the soil called semi dry (SD) seed bed. In low land seed beds were always in water saturated condition (sometimes standing water) called wet seed bed (W). The sprouted seeds were sown treatment wise in seed bed.

\subsection{Effect of Bakanae Disease on Yield and Yield Contributing Factors of Rice}

Effect of bakanae disease on yield and yield contributing factors of tested rice varieties, effect of healthy and bakanae infected tiller on seedling mortality and yield loss, interaction effect between variety and tiller status on seedling mortality and yield loss due to bakanae disease and effect of different seed treatments on yield and yield attributing characters were observed.

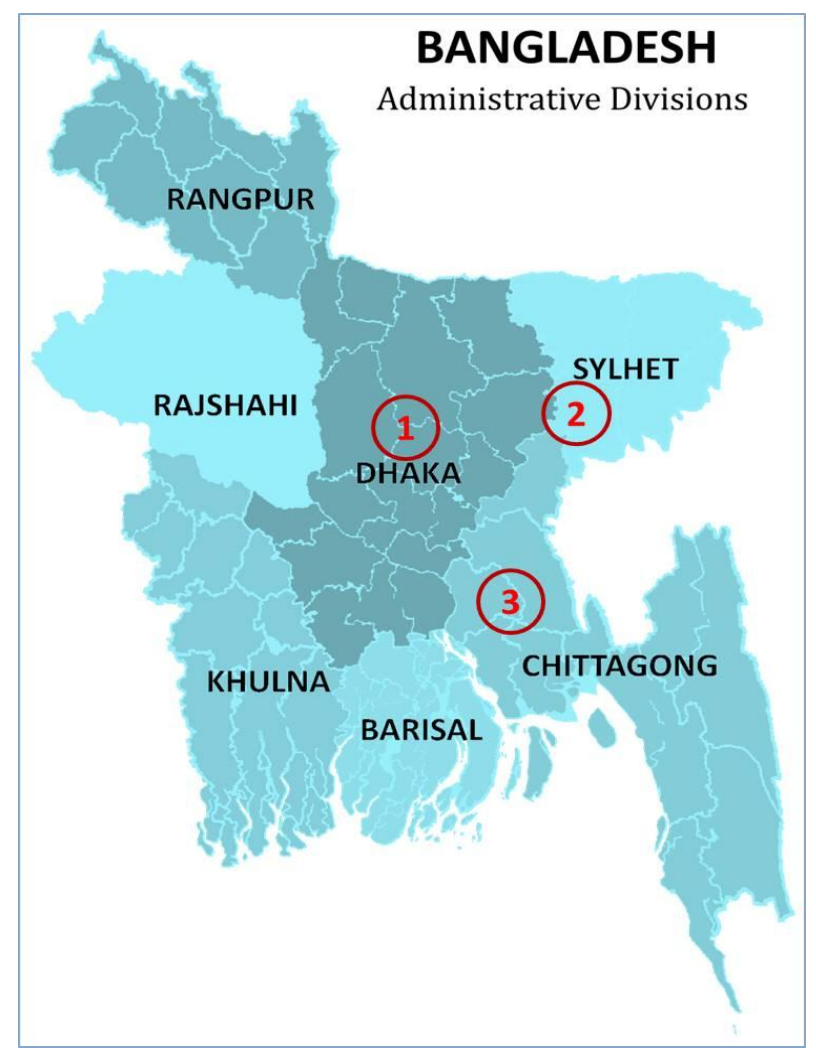

Figure 1. Experimental site: (1) Gazipur, (2) Hobigonj and (3) Cumilla districts of Bangladesh which is comprised of Dhaka, Sylhet and Chittagong Divisions, respectively.

Data collection: Data on average of two seasons on the \% hill infection, \% tiller infection, yield and yield attributing characters were recorded. 


\section{Results and Discussion}

\subsection{Detection of Different Fungi on Bakanae Infected Seeds}

From the tested seeds, the fungus Aspergillus niger was observed as the highest in number followed by Aspergillus flavus, Penicillium sp., Bipolaris oryzae, Pyryicularia oryzae, Curvularia sp., Fusarium moniliforme and Alternaria padwickii.

\subsection{Management of Bakanae Disease through Seed Treatments}

3.2.1. Effect of Seed Treatments on the Incidence of Fusarium moniliformae in vitro

The results showed that five fungicides namely Bavistin, Knowin, Haydazim, Topsil plus and Sunphanate @ 0.3\% were effective for reducing the incidence of $F$. moniliformae, causing bakanae disease of rice (BR16) both in 7 and 15 days after incubation (Table 1). In addition, Cupravit, Pipertox and win gave good result after 15 days of incubation. A successful chemical control was reported by Hossain et al. [16].

Table 1. Efficacy of different fungicides on the incidence of $F$. moniliforme after 7 and 15 days of incubation

\begin{tabular}{|c|c|c|c|}
\hline Fungicides & Active ingredient & \multicolumn{2}{|c|}{$\begin{array}{c}\text { Incidence of fungi } \\
\text { (\%) after incubation }\end{array}$} \\
\hline & & 7 days & 15 days \\
\hline Bavistin WP & Carbendazim 50\% & 0 & 0 \\
\hline Knowin WP & Carbendazim 50\% & 0 & 0 \\
\hline Ecozim WP & Carbendazim 50\% & 0 & 0 \\
\hline $\begin{array}{c}\text { Haydazim } \\
\text { WP }\end{array}$ & Carbendazim 50\% & 0 & 0 \\
\hline $\begin{array}{c}\text { Companion } \\
\text { WP }\end{array}$ & Mancozeb+Carbendazim & 0 & 2.5 \\
\hline Pharzeb WP & Mancozeb 80 WP & 0 & 10 \\
\hline Dencozeb WP & Mancozeb 80 WP & 0.5 & 5 \\
\hline Meena WP & Mancozeb & 0 & 6.51 \\
\hline Sulcox WP & Copper oxichloride 50\% & 2.5 & 20.5 \\
\hline Oxyvit WP & Copper oxichloride 50\% & 1 & 12.5 \\
\hline Cupravit WP & Copper oxichloride 50\% & 6.5 & 10.0 \\
\hline Pipertox WP & Copper oxichloride 50\% & 6.5 & 2.0 \\
\hline Win WP & Copper hydroxide 77\% & 5.5 & 12.0 \\
\hline Sulfex WP & Sulphur 80\% & 3.5 & 12.0 \\
\hline Trooper WP & Trycyclazole 75\% & 3 & 22.0 \\
\hline $\begin{array}{c}\text { Greensul } \\
\text { WDG }\end{array}$ & Sulphur 80\% & 10.5 & 16.0 \\
\hline Zeal WP & Trycyclazole 75\% & 4.5 & 15.0 \\
\hline $\begin{array}{c}\text { Topsil plus } \\
\text { WP }\end{array}$ & Thiophanate methyl 80\% & 0 & 0 \\
\hline $\begin{array}{c}\text { Sunphanate } \\
\text { WP }\end{array}$ & Thiophanate methyl 80\% & 1 & 4.0 \\
\hline Ridomil WP & MetalaxylN+Mancozeb & 3 & 6.0 \\
\hline Rovral WP & Iprodione50\% & 2.5 & 10.0 \\
\hline Control & - & 12.5 & 23.0 \\
\hline
\end{tabular}

3.2.2. Effect of Seed Treatments on the Incidence of Bakanae Disease in Seedbed Condition

Bakanae incidence was absent in five fungicides namely, Bavistin, Knowin, Haydazim, Topsil plus, Sunphanate and Companion@ $0.3 \%$ at 15 and 30 DAS (Days after sowing) while incidence was very low in Trooper@ $0.3 \%$ at 30 DAS compared to control (Table 2).

Table 2. Effect of seed treatments on the incidence of bakanae disease in vivo (seedbed condition)

\begin{tabular}{|c|c|c|}
\hline \multirow{2}{*}{ Fungicides } & \multicolumn{2}{|c|}{ \% Bakanae incidence } \\
\cline { 2 - 3 } & 15 DAS & 30 DAS \\
\hline Bavistin & 0 & 0 \\
\hline Knowin & 0 & 0 \\
\hline Haydazim & 0 & 0 \\
\hline Companion & 0 & 0 \\
\hline Pharzeb & 1 & 3 \\
\hline Cupravit & 10 & 11 \\
\hline Sulfex & 6 & 7 \\
\hline Topsil plus & 0 & 0 \\
\hline Sunphanate & 0 & 0 \\
\hline Ridomil & 5 & 8 \\
\hline Trooper & 0 & 2 \\
\hline Rovral & 4 & 6 \\
\hline Control & 9 & 10 \\
\hline
\end{tabular}

The in vitro and in vivo studies indicated that Bavistin, Knowin, Haydazim, Topsil plus and Sunphanate could be effective chemicals for controlling bakanae disease. The result suggests that carbendazim and thiophenate methyl group could be effective for inhibition or suppression of the growth of bakanae causing pathogen. The fungicidal suspension under carbendazim group was also effective against bakanae disease [19]. Seed treatments with fungicide, thiophanate-methyl (homai) also effective against bakanae disease reported by Miah and Shahjahan [20] and Rathaiah [21]. Earlier researchers also identified that mercurial compounds are not good to control bakanae disease compared to non-mercurial compounds [22]. So, these five fungicides namely, Bavistin, Knowin, Haydazim, Topsil plus and Sunphanate could be used for the control of bakanae disease.

\subsection{Management of Bakanae Disease through Root Dipping of Rice Seedling}

Bakanae disease incidence at 25 and 45 DAT (days after transplanting) was absent or very low in all the farmers field trial when seedling roots were dipped overnight with Bavistin and Knowin before transplanting. Root dipping with the fungicides (carbendazim group) Bavistin and Knowin@0.3\% was effective very much to control bakanae disease in the field compared to Ridomil (Table 3). 
This result corroborates with results of Latif et al. [19]. Sarkar [23] tested 8 fungicides against Gibberella fujikuroi on rice, carbendazim gave the best results, followed by PCNB (quintozene) and Agrosan, although none gave complete control. Root dipping method is found to be good as absorption of chemicals occurs rapidly in rice through root dipping [24]. In addition, Fusarium wilt of banana was significantly reduced when applied as root dip treatment [25]. So this technology could be used for further dissemination. Rogueing is comparatively better than control to manage the disease in field.

\subsection{Management of Bakanae Disease at Field Condition}

Considering all farmers' field trials, none of the fungicides namely Bavistin, Knowin, Ridomil, Forastin, Sunphanate and Cupravit @ 0.3\% were effective against bakanae compared to rogueing when those were sprayed in the standing crop at tillering stage (Table 4). Halil and Halim [26] found similar results when they sprayed different fungicides in field condition. Disease incidence of bakanae disease in the field did not reduce with the application of carboxin (as Vitavax) as reported by Khan et al. [27].

On the other hand, it is reported that seed infection by Gibberella fujikuroi can be minimized with chemical if applied at flowering stage [28]. Further field evaluations of the fungicides are required to control bakanae disease at different growth stages.

\subsection{Effect of Seed Bed Condition and Fungicides for the Control of Bakanae Disease}

Effect of seed bed condition: The effect of seed bed condition on $\%$ of banakae infected hill, $\%$ of bakanae infected tiller/hill of rice was recorded and the result are presented in Table 4. It was observed that the seedbed conditions differed significantly in respect of $\%$ of bakanae infected hill and was insignificant in respect of \% bakanae infected tiller/hill. The bakanae infected hill ranged from 0.31 to $3.45 \%$ (Table 5). The highest bakanae infected hill $3.45 \%$ was observed in dry (D) seedbed which was statistically significant compared to semi dry (SD) seedbed.

Table 3. Management of bakanae disease through root dipping in seed bed

\begin{tabular}{|c|c|c|c|c|c|c|c|c|c|c|c|c|}
\hline \multirow{3}{*}{ Treatment } & \multicolumn{12}{|c|}{ Bakanae incidence $(\%)$} \\
\hline & \multicolumn{3}{|c|}{ Field 1} & \multicolumn{3}{|c|}{ Field 2} & \multicolumn{3}{|c|}{ Field 3} & \multicolumn{3}{|c|}{ Field 4} \\
\hline & Initial & $\begin{array}{c}25 \\
\text { DAT }\end{array}$ & 45 DAT & Initial & $\begin{array}{c}25 \\
\text { DAT }\end{array}$ & $\begin{array}{c}45 \\
\text { DAT }\end{array}$ & Initial & $\begin{array}{c}25 \\
\text { DAT }\end{array}$ & $\begin{array}{c}45 \\
\text { DAT }\end{array}$ & Initial & $\begin{array}{c}25 \\
\text { DAT }\end{array}$ & $\begin{array}{c}45 \\
\text { DAT }\end{array}$ \\
\hline Bavistin & 6.75 & 0 & 0 & 5.33 & 0 & 0 & 14.5 & 0 & 0 & 5.4 & 0.15 & 0 \\
\hline Knowin & 6.75 & 0 & 0 & 5.33 & 0 & 0 & 14.5 & 0.2 & 0 & 5.4 & 0.28 & 0 \\
\hline $\begin{array}{l}\text { Ridomil } \\
\text { MZ }\end{array}$ & 6.75 & 1.5 & 6.5 & 5.33 & 1.0 & 3.5 & 14.5 & 8.25 & 2.3 & 5.4 & 1.5 & 2.6 \\
\hline $\begin{array}{l}\text { Rouging at } \\
\text { seedbed }\end{array}$ & 6.75 & 2.0 & 6.3 & 5.33 & 1.5 & 4.5 & 14.5 & 10.7 & 4.4 & 5.4 & 2.8 & 3.6 \\
\hline $\begin{array}{l}\text { Rouging at } \\
25 \text { DAT }\end{array}$ & 6.75 & 4.0 & 2.5 & 5.33 & 3.5 & 1.5 & 14.5 & 10.9 & 3.2 & 5.4 & 5.9 & 2.1 \\
\hline Control & 6.75 & 4.0 & 7.5 & 5.33 & 3.5 & 7.5 & 14.5 & 7.5 & 7.0 & 5.4 & 5.1 & 5.0 \\
\hline
\end{tabular}

Table 4. Efficacy of fungicides for the control of bakanae disease in Aus 2007 on BR1

\begin{tabular}{|c|c|c|c|}
\hline \multirow{2}{*}{ Treatments } & \multicolumn{2}{|c|}{ Bakanae incidence (\%) } & \multirow{2}{*}{$\%$ reduction } \\
\hline & 25 DAT (Initial) & 45 DAT & \\
\hline Rogueing + Sunphanate @ 0.3\% & \multirow{8}{*}{5.2} & 5.8 & \multirow{8}{*}{ No reductior } \\
\hline Rogueing + Knowin@ 0.3\% & & 5.9 & \\
\hline Rogueing + Bavistin @ 0.3\% & & 7.2 & \\
\hline Rogueing + Ridomil @ 0.3\% & & 7.0 & \\
\hline Rogueing + Bavistin @ 0.3\% & & 7.2 & \\
\hline Rogueing + Ridomil @ 0.3\% & & 7.0 & \\
\hline Rogueing of infected tiller at 25DAT & & 5.6 & \\
\hline No Rogueing + fungicides (Control) & & 7.8 & \\
\hline
\end{tabular}


The lowest bakanae infected hill was recorded in $\mathrm{W}$ (wet seed bed). The range of bakanae infected tiller/hill was from 17.46-19.90\% (Table 5). There was no significant difference among the seedbed conditions in respect of bakanae infected tiller hill-1.

Table 5. Seed bed condition effects on the incidence of bakanae disease

\begin{tabular}{|c|c|c|}
\hline $\begin{array}{l}\text { Seedbed } \\
\text { condition }\end{array}$ & $\begin{array}{c}\% \text { bakanae infected } \\
\text { hill }\end{array}$ & $\begin{array}{c}\% \text { bakanae infected } \\
\text { tiller hill-1 }\end{array}$ \\
\hline Dry (D) & $3.45 \mathrm{a}$ & $17.46 \mathrm{a}$ \\
\hline Semi dry (SD) & $2.18 b$ & $19.90 \mathrm{a}$ \\
\hline Wet (W) & $0.31 \mathrm{c}$ & $19.73 a$ \\
\hline $\operatorname{LSD}(\mathrm{P}=0.05)$ & 0.421 & 3.1 \\
\hline
\end{tabular}

In a column means followed by a common small letter(s) are not different significantly at 5\% level of LSD.

Effect of seed treatment: Results on the effect of seed treatment on bakanae infected hill (\%) and bakanae infected tiller/hill (\%) of rice were recorded and results are presented in Table 6. It was observed that the treatments differed significantly in respect of bakanae infected hill (\%) and bakanae infected tiller hill ${ }^{-1}(\%)$ of rice. The bakanae infected hill ranged from 0.45 to $1.92 \%$, where the highest bakanae infected hill (\%) was observed in infected seed and the lowest was observed in Healthy seed. The bakanae infected tiller/hill ranged from $13.19-25.31 \%$, where the higher $\%$ of bakanae infected tiller was observed in infected seed and the lowest \% of bakanae infected tiller/hill was observed in healthy seed. Similar result was described by Sunani et al. [29].

Table 6. Effect of seed treating fungicide on the incidence of bakanae disease of rice

\begin{tabular}{|c|c|c|}
\hline Treatment & $\begin{array}{c}\text { \% bakanae infected } \\
\text { hill }\end{array}$ & $\begin{array}{c}\text { \% bakanae } \\
\text { infected tiller/hill }\end{array}$ \\
\hline Infected seed & $1.92 \mathrm{a}$ & $25.31 \mathrm{a}$ \\
\hline $\begin{array}{c}\text { Infected seed treated } \\
\text { with homai }\end{array}$ & $0.56 \mathrm{~b}$ & $18.59 \mathrm{ab}$ \\
\hline Healthy & $0.45 \mathrm{~b}$ & $13.19 \mathrm{~b}$ \\
\hline LSD (P=0.05) & 0.2309 & 7.082 \\
\hline
\end{tabular}

Effect of interaction between seed treatments and seed bed conditions on bakanae disease incidence: The effect of interaction between seed treatment and seedbed conditions showed significant variation on $\%$ of bakanae infected hill and \% of bakanae infected tiller/hill of rice (Table 7$)$. The lowest $(0.39 \%)$ bakanae infected hill was observed at wet seed bed with healthy seed follow by wet seed bed with infected but treated seed and wet seed bed with infected seed. There was no significant difference among wet seed beds with different treatments. The highest $\%$ of bakanae infected hill was recorded from dry seed bed with infected seed followed by dry seed bed with infected seed but treated and dry seed bed with healthy seed. There was no significant difference between dry seed bed with treated seed and dry seed bed with healthy seed but significantly differed with dry seed bed with infected seed.

Healthy plant means not infected by bakanae disease and diseased plant means infected by bakanae disease. The bakanae infected tiller/hill at maximum tillering stage for three seed bed conditions ranged from 10.37 to $17.11 \%$. Where the highest $\%$ of bakanae infected tiller/hill observed in SD and the lowest observed in W. In case of booting stage, the highest (24.41) and the lowest (17.87) observed in $\mathrm{W}$ and $\mathrm{D}$. In case of grain filling stage, data were same as booting stage.

Interaction effect of seed treatments and three growth stages of rice on the incidence of bakanae infected hill and bakanae infected tiller/hill: Results on the effect of different seed treatments in controlling bakanae disease of rice at three stages of crop growth viz. maximum tillering, booting, grain filling stages with respect to \% bakanae infected hill and \% bakanae infected tiller/hill was determined and are presented in Table 8 . The average $\%$ of bakanae infected hill and \% of bakanae infected tiller/hill in all seed treatments $\left(\mathrm{T}_{1}, \mathrm{~T}_{2}\right.$ and $\left.\mathrm{T}_{3}\right)$ were increased from maximum tillering to booting stage. But there were no increase in grain filling stage of the plant. All the seed treatments were statistically insignificant. In maximum tillering stage, $\%$ of bakanae infected hill for all treatments ranged from 0.35 to 1.81 , where the highest (1.81) and the lowest (0.35) were counted in $T_{1}$ (infected seed, non-treated) and $\mathrm{T}_{2}$ (infected seed but treated with Homai) respectively. In case of booting stage maximum (1.98) and minimum (0.50) were observed in $\mathrm{T}_{1}$ (infected) and $\mathrm{T}_{3}$ (healthy), respectively. In case of grain filling stage, $\%$ of bakanae infected hill were as same as booting stage. The bakanae infected tiller/hill at maximum tillering stage for all seed treatments ranged from 9.87 to $20.96 \%$, where the highest (20.96) and the lowest (9.87) observed in $\mathrm{T}_{1}$ (infected seed, non-treated) and $\mathrm{T}_{3}$ (healthy). In case of booting stage the highest (27.48) and the lowest (14.85) observed in $\mathrm{T}_{1}$ (infected seed, non-treated) and $\mathrm{T}_{3}$ (healthy), respectively. In grain filling stage, $\%$ of bakanae infected tiller/hill was the same as booting stage. Similar results were described by Bashyal [1] and Pooja et al.[2]. 
Table 7. Interaction effect between seed treatments and seedbed condition on the incidence of bakanae infected hill and bakanae infected tiller/hill

\begin{tabular}{|c|c|c|c|c|c|c|}
\hline \multirow{2}{*}{ Treatment } & \multicolumn{3}{|c|}{ \% bakanae infected hill } & \multicolumn{3}{c|}{$\%$ bakanae infected tiller/hill } \\
\cline { 2 - 7 } & Infected seed & $\begin{array}{c}\text { Infected seed } \\
\text { but treated }\end{array}$ & Healthy & Infected seed & $\begin{array}{c}\text { Infected seed but } \\
\text { treated }\end{array}$ & Healthy \\
\hline Dry (D) & $2.70 \mathrm{a}$ & $0.83 \mathrm{~b}$ & $0.82 \mathrm{ba}$ & $16.42 \mathrm{a}$ & $17.64 \mathrm{a}$ & 18.32 \\
\hline Semidry (SD) & $2.68 \mathrm{a}$ & $0.53 \mathrm{~b}$ & $0.32 \mathrm{ba}$ & $30.60 \mathrm{a}$ & $14.18 \mathrm{~b}$ & $14.92 \mathrm{~b}$ \\
\hline Wet (W) & $0.39 \mathrm{a}$ & $0.32 \mathrm{a}$ & $0.21 \mathrm{a}$ & $28.90 \mathrm{a}$ & $23.95 \mathrm{a}$ & $6.34 \mathrm{~b}$ \\
\hline LSD (P=0.05) & \multicolumn{3}{|c|}{0.399} & & 2.27 \\
\hline
\end{tabular}

Table 8. Interaction effect of different seed treatments and three growth stages of rice on the incidence of bakanae infected hill and bakanae infected tiller/hill

\begin{tabular}{|c|c|c|c|c|c|c|}
\hline \multirow{2}{*}{ Treatment } & \multicolumn{3}{|c|}{$\%$ bakanae infected hill } & \multicolumn{3}{c|}{$\%$ bakanae infected tiller/hill } \\
\cline { 2 - 7 } & $\begin{array}{c}\text { Maximum } \\
\text { tillering stage }\end{array}$ & Booting stage & $\begin{array}{c}\text { Grain filling } \\
\text { stage }\end{array}$ & $\begin{array}{c}\text { Maximum } \\
\text { tillering stage }\end{array}$ & $\begin{array}{c}\text { Booting stage } \\
\text { Grain filling } \\
\text { stage }\end{array}$ \\
\hline Infected seed $\left(\mathrm{T}_{1}\right)$ & $1.81 \mathrm{a}$ & $1.98 \mathrm{a}$ & $1.98 \mathrm{a}$ & $20.96 \mathrm{a}$ & $27.48 \mathrm{a}$ & $27.48 \mathrm{a}$ \\
\hline $\begin{array}{c}\text { Infected seed but } \\
\text { treated }\left(\mathrm{T}_{2}\right)\end{array}$ & $0.35 \mathrm{a}$ & $0.67 \mathrm{a}$ & $0.67 \mathrm{a}$ & $13.29 \mathrm{a}$ & $21.24 \mathrm{a}$ & $21.24 \mathrm{a}$ \\
\hline Healthy $\left(\mathrm{T}_{3}\right)$ & $0.36 \mathrm{a}$ & $0.50 \mathrm{a}$ & $0.50 \mathrm{a}$ & $9.87 \mathrm{a}$ & $14.85 \mathrm{a}$ & $14.85 \mathrm{a}$ \\
\hline
\end{tabular}

In a column means followed by a common small letter(s) are not different significantly at $5 \%$ level of LSD.

\subsection{Effect of Bakanae Disease on Yield and Yield Contributing Factors of Rice}

Table 9. Effect of bakanae disease on yield and yield contributing factors of tested rice varieties

\begin{tabular}{|c|c|c|c|c|c|}
\hline $\begin{array}{c}\text { Hill } \\
\text { Status }\end{array}$ & $\begin{array}{c}\text { No. } \\
\text { tiller/hill }\end{array}$ & $\begin{array}{c}\text { No. } \\
\text { panicle/hill }\end{array}$ & $\begin{array}{c}\% \\
\text { Filled } \\
\text { grain }\end{array}$ & $\begin{array}{c}1000 \mathrm{~g} \\
\mathrm{Wt}\end{array}$ & $\begin{array}{c}\text { Grain } \\
\text { yield } \\
(\mathrm{gm}) / \mathrm{hill}\end{array}$ \\
\hline \multicolumn{6}{|c|}{ BR1 } \\
\hline Infected & 10.83 & 10.09 & 59.49 & 19.81 & 8.09 \\
\hline Healthy & 15.94 & 14.19 & 64.55 & 19.72 & 10.41 \\
\hline LSD0.05 & 2.16 & 1.64 & 3.51 & $\mathrm{Ns}$ & 1.09 \\
\hline \multicolumn{7}{|c|}{ BRRI dhan29 } \\
\hline Infected & 11.41 & 8.84 & 65.38 & 20.76 & 13.31 \\
\hline Healthy & 13.30 & 12.11 & 70.29 & 21.06 & 19.26 \\
\hline LSD0.05 & 0.94 & 2.03 & 2.29 & Ns & 0.85 \\
\hline
\end{tabular}

Effect of bakanae disease on yield and yield contributing factors of tested rice varieties: Fifty Bakanae infected hills from each of BRRI dhan29 and BR1 were tagged in the farmers' field in transplanted rainfed upland ecosystem in Habigonj district. Data on no. of tiller/hill, no. of panicle/hill, yield and yield components were recorded. The attributes under consideration significantly varied between healthy and infected hills
(Table 9). In BR1 variety grain yield was $8.09 \mathrm{~g} / \mathrm{hill}$ in infected plant and $10.41 \mathrm{~g} /$ hill in healthy plant. In BRRI dhan 29 grain yield was higher in healthy plant $(19.26 \mathrm{~g} / \mathrm{hill})$ than infected plant (13.31 g/hill). Pavgi and Singh [10] reported the similar results.

Effect of bakanae disease on the seedling mortality and yield loss: The effect of healthy and bakanae infected tiller on percent seedling mortality, $\%$ tiller from $1^{\text {st }}$ node, number of tiller/hill, grain/pot and yield loss are presented in Table 10. It was observed that healthy and infected tiller showed significant variation on the seedlings mortality, \% tiller from $1^{\text {st }}$ node, number of tiller/hill and grain/pot. Considering both the varieties, $25.32 \%$ yield loss was obtained due to bakanae disease infection which was similar to the result of BRRI [12].

Effect of interaction between varieties and tiller status: The effect of interaction between tiller status and varieties showed significant variation on $\%$ of seedling mortality, $\%$ of tiller from $1^{\text {st }}$ node, number of tiller/hill and grain/pot of rice. In case of infected tiller, the percentage of seedlings mortality, tiller from $1^{\text {st }}$ node was higher at variety swarna, while no. of tiller/hill, grain/pot was lower compared to BR22. Yield loss due to bakanae was $26.70 \%$ in variety swarna while $24.12 \%$ in BR22 (Table 11). Ito and Kimura [9] reported similar yield loss which was in agreement with the present results. 
Table 10. Effect of healthy and bakanae infected tiller on seedling mortality and yield loss

\begin{tabular}{|c|c|c|c|c|c|}
\hline Treatments & \% seedling mortality & $\begin{array}{c}\text { \% tiller from 1st } \\
\text { node }\end{array}$ & Number of tiller/hill ${ }^{\mathrm{a}}$ & Grain/ pot (g) & Yield loss (\%) \\
\hline Infected & $26.65 \mathrm{a}$ & $10.30 \mathrm{a}$ & $12.20 \mathrm{~b}$ & $18.96 \mathrm{c}$ & 25.32 \\
\hline Healthy & $0.00 \mathrm{c}$ & $0.00 \mathrm{c}$ & $17.70 \mathrm{a}$ & $25.39 \mathrm{a}$ & \\
\hline LSD (P=0.05) & 0.742 & 0.185 & 0.722 & 0.636 & \\
\hline
\end{tabular}

In a column means followed by a common letter(s) are not significant different at $5 \%$ level. ${ }^{\text {a }}$ - No. of tiller/hill was average of dead and survived plants.

Table 11. Interaction effect between variety and tiller status on seedling mortality and yield loss due to bakanae disease

\begin{tabular}{|c|c|c|c|c|c|c|c|}
\hline \multirow{2}{*}{ Variety } & \multicolumn{2}{|c|}{$\%$ seedling mortality } & \multicolumn{2}{|c|}{ No. of tiller/hill } & \multicolumn{2}{|c|}{ Grain/pot } & \multirow{2}{*}{$\begin{array}{l}\text { Yield loss } \\
(\%)\end{array}$} \\
\hline & Infected & Healthy & Infected & Healthy & Infected & Healthy & \\
\hline Swarna & $30.00 \mathrm{a}$ & $0.00 \mathrm{c}$ & $11.00 \mathrm{c}$ & $17.40 \mathrm{a}$ & $17.35 \mathrm{~d}$ & $23.67 \mathrm{~b}$ & 26.70 \\
\hline BR22 & $23.30 \mathrm{~b}$ & $0.00 \mathrm{c}$ & $13.40 \mathrm{~b}$ & $18.00 \mathrm{a}$ & $20.57 \mathrm{c}$ & $27.11 \mathrm{a}$ & 24.12 \\
\hline
\end{tabular}

In a column means followed by a common small letter(s) are not different significantly at 5\% level of LSD.

Effect of different seedbed condition on yield and yield attributing characters: The treatments i.e. three seed bed conditions were found to be statistically non-significant in respect of effective tiller $/ \mathrm{m}^{2}$, panicle length (cm), number of spikelets/panicle, filled grain/panicle, unfilled grain/panicle, 1000-grain weight (g) and yield (t/ha) are presented in the Table 12. The highest effective tiller $/ \mathrm{m}^{2}$ was observed in $\mathrm{W}$ (wet seed bed) and the lowest was observed in D (dry seed bed). Total number of effective tiller $/ \mathrm{m}^{2}$ among the seed bed condition ranged from 365.33 to 392.67 . The panicle length among the seed bed conditions ranged from 25.11 to $25.68 \mathrm{~cm}$. The number of spikelets/panicle ranged from 136.67 to 161.75 , where the highest number of spikelets/panicle (161.75) was obtained in SD (semi dry seed bed) and the lowest number of spikelets/panicle (136.67) was in W (wet seed bed). The range of filled grain/panicle was from 97.21 to 113.63 , where the highest (113.63) in SD (semi dry seed bed) and the lowest (97.21) in D (dry seed bed). The number of unfilled grain/panicle among the seed bed condition ranged from 33.78 to 48.13 , where the highest (48.13) was in SD (semi dry seed bed) and the lowest (33.78) in W (wet seed bed). The range of 1000-grain weight was from 18.98 to $19.10 \mathrm{~g}$. The yield was differed non-significantly among the seedbed conditions. Those were statistically similar but had some numerical differences. The highest (4.58 t/ha) and the lowest (4.34 t/ha) yield was observed in $\mathrm{W}$ (wet seed bed) and D (dry seed bed), respectively. Yield loss occurred due to this disease at dry and semi dry seed bed over wet seed bed conditions were $5.24 \%$ and $1.04 \%$, respectively. Fiyaz et al. [4] and Bashyal et al. [5] described the similar results.
Effect of different seed treatments on yield and yield attributing characters: The treatments were found to be non-significant in respect of effective tiller $/ \mathrm{m}^{2}$, panicle length (cm), number of spikelets/panicle, filled grain/panicle, unfilled grain/panicle, 1000-grain weight (g) and yield (t/ha) are presented in Table 13. The highest no. of effective tiller/ $\mathrm{m}^{2}$ was observed in $\mathrm{T}_{3}$ (healthy seed) and lowest in $\mathrm{T}_{1}$ (infected). The effective tiller $/ \mathrm{m}^{2}$ was ranged from 379.22 to 381.67 . The panicle length ranged from 25.30 to $25.72 \mathrm{~cm}$, where the highest $(25.72 \mathrm{~cm})$ was observed in $\mathrm{T}_{3}$ (healthy) and the lowest was observed in $\mathrm{T}_{2}$ (infected seed but treated with Homai). The number of spikelets ranged from 139.65 to 154.87 , where the highest was observed in $\mathrm{T}_{3}$ (healthy) and the lowest was in $\mathrm{T}_{1}$ (infected seed, non-treated). The highest (111.67) filled grain/panicle was observed in $\mathrm{T}_{2}$ (infected seed, treated with homai) and the lowest (93.42) was in $\mathrm{T}_{1}$ (infected seed). The ranged of filled grain/panicle observed from 93.42 to 111.67 . The unfilled grain/panicle ranged from 38.74 to 46.23 , where higher (46.23) and lower (38.74) were observed in $\mathrm{T}_{1}$ (infected seed) and $\mathrm{T}_{2}$ (infected seed but treated with homai) respectively. The ranged of 1000-grain weight (g) observed from 18.96 to $19.10 \mathrm{~g}$, and there was no significant difference among the treatments. The highest yield (4.58 t/ha) was found in $\mathrm{T}_{3}$ (healthy) and the lowest yield (4.29 $\mathrm{t} / \mathrm{ha}$ ) was recorded in $\mathrm{T}_{1}$ (infected seed, non-treated). The yield was ranged from 4.29 to 4.58 $\mathrm{t} / \mathrm{ha}$. The estimated yield loss at $\mathrm{T}_{1}$ (infected seed) and $\mathrm{T}_{2}$ (infected seed but treated) over $\mathrm{T}_{3}$ (healthy seed) were $6.33 \%$ and $0.44 \%$ respectively. Ochi et al. [28], Kumar et al. [31] and Hossain et al. [32] observed the similar result. 
Table 12. Effect of different seedbed conditions on yield and yield attributing characters

\begin{tabular}{|c|c|c|c|c|c|c|c|c|}
\hline $\begin{array}{c}\text { Seedbed } \\
\text { condition }\end{array}$ & $\begin{array}{c}\text { Effective } \\
\text { tiller/m² }\end{array}$ & $\begin{array}{c}\text { Panicle } \\
\text { length } \\
(\mathrm{cm})\end{array}$ & $\begin{array}{c}\text { No. of } \\
\text { Spikelets } \\
\text { /panicle }\end{array}$ & $\begin{array}{c}\text { Filled grain/ } \\
\text { panicle }\end{array}$ & $\begin{array}{c}\text { Unfilled } \\
\text { grain/ } \\
\text { panicle }\end{array}$ & $\begin{array}{c}\text { 1000-grain } \\
\text { weight (g) }\end{array}$ & $\begin{array}{c}\text { Yield } \\
\text { (t/ha) }\end{array}$ & $\begin{array}{c}\% \text { yield loss } \\
\text { over wet } \\
\text { seed bed }\end{array}$ \\
\hline D (Dry) & $365.3 \mathrm{a}$ & $25.1 \mathrm{a}$ & $146.5 \mathrm{a}$ & $97.2 \mathrm{a}$ & $44.7 \mathrm{a}$ & $19.1 \mathrm{a}$ & $4.3 \mathrm{a}$ & 5.4 \\
\hline SD (Semi dry) & $383.7 \mathrm{a}$ & $25.7 \mathrm{a}$ & $161.8 \mathrm{a}$ & $113.6 \mathrm{a}$ & $48.1 \mathrm{a}$ & $18.98 \mathrm{a}$ & $4.5 \mathrm{a}$ & 1.0 \\
\hline W (Wet) & $392.7 \mathrm{a}$ & $25.7 \mathrm{a}$ & $136.7 \mathrm{a}$ & $102.8 \mathrm{a}$ & $33.8 \mathrm{a}$ & $19.0 \mathrm{a}$ & 4.6 & - \\
\hline
\end{tabular}

In a column means followed by a common small letter(s) are not different significantly at $5 \%$ level of LSD.

Table 13. Effect of different seed treatments on yield and yield attributing characters

\begin{tabular}{|c|c|c|c|c|c|c|c|c|}
\hline Treatment & $\begin{array}{c}\text { Effective } \\
\text { tiller/m² }\end{array}$ & $\begin{array}{c}\text { Panicle } \\
\text { length } \\
\text { (cm) }\end{array}$ & $\begin{array}{c}\text { No. of } \\
\text { Spikelet/panicle }\end{array}$ & $\begin{array}{c}\text { Filled } \\
\text { grain/ } \\
\text { panicle }\end{array}$ & $\begin{array}{c}\text { Unfilled } \\
\text { grain/ } \\
\text { panicle }\end{array}$ & $\begin{array}{c}\text { 1000-grain } \\
\text { weight (g) }\end{array}$ & $\begin{array}{c}\text { Yield } \\
\text { (t/ha) }\end{array}$ & $\begin{array}{c}\% \text { Yield } \\
\text { loss over } \\
\text { healthy } \\
\text { seed }\end{array}$ \\
\hline $\begin{array}{c}\text { Infected seed } \\
\text { (T1) }\end{array}$ & $379.0 \mathrm{a}$ & $25.4 \mathrm{a}$ & $139.7 \mathrm{a}$ & $93.4 \mathrm{a}$ & $46.2 \mathrm{a}$ & $19.0 \mathrm{a}$ & $4.3 \mathrm{a}$ & 6.3 \\
\hline $\begin{array}{c}\text { Infected seed } \\
\text { treated (T2) }\end{array}$ & $381.0 \mathrm{a}$ & $25.3 \mathrm{a}$ & $150.4 \mathrm{a}$ & $111.7 \mathrm{a}$ & $38.7 \mathrm{a}$ & $19.1 \mathrm{a}$ & $4.6 \mathrm{a}$ & 0.4 \\
\hline $\begin{array}{c}\text { Healthy seed } \\
\text { (T3) }\end{array}$ & $381.7 \mathrm{a}$ & $25.7 \mathrm{a}$ & $154.9 \mathrm{a}$ & $108.6 \mathrm{a}$ & $41.6 \mathrm{a}$ & $18.96 \mathrm{a}$ & 4.6 & - \\
\hline
\end{tabular}

In a column means followed by a common small letter(s) are not different significantly at 5\% level of LSD.

\section{Conclusions}

From our results, it seems that Bavistin, Knowin, Haydazim, Topsil plus and Sunphanate could be effective as seed treating fungicides against bakanae disease. Seed treatment with Bavistin and Knowin might be effective to control bakanae disease. Wet seed bed reduced the $\%$ of bakanae infected hill in comparison with semi dry and dry in seedbed condition. In combination with seed bed conditions and seed treatments, wet seed bed with healthy or infected seed but treated with homai reduced the bakanae incidence. Semi dry seed bed with healthy or infected seed but treated with homai also control the bakanae disease compared to dry seed bed. Further researches are needed to confirm the results.

\section{REFERENCES}

[1] Bashyal BM, "Etiology of an emerging disease: bakanae of rice," Indian Phytopath. 71, 485-494. 2018. https://doi.org/10.1007/s42360-018-0091-2

[2] Pooja K., Abhishek K., Mahendra P., U. Shristi, "Bakanae of Rice: A Serious Disease in Punjab," Int. J. Curr. Microbiol. App. Sci. 8(5): 129-136. 2019. DOI: https://doi.org/10.2054 6/ijcmas.2019.805.017

[3] Bashyal BM., Aggarwal R., Rawat K., Sharma S., Gupta AK., Choudhary R., Bhat J., Krishnan SG., AK. Singh, "Genetic diversity and population structure of Fusarium fujikuroi causing Bakanae, an emerging disease of rice in Indi," Indian J. Experiment. Biol. 58, pp. 45-52. 2020.

[4] Fiyaz RA., Yadav AK., Krishnan SG., Ellur RK., Bashyal BM., N. Grover et al., "Mapping quantitative trait loci responsible for resistance to bakanae disease in rice," Rice 9:45. 2016. https://doi.org/10.1186/s12284-016-0117-2
[5] Bashyal BM., Rawat K., Sharma S., Kulshrestha D., Singh AK., Dubey H., Solanki AKU., Sharma TR., R. Aggarwal, "Whole genome sequencing of Fusarium fujikuroi provides insight into the role of secretory proteins and cell wall degrading enzymes in causing bakanae disease of rice," Frontiers Plant Sci. 2017. https://doi.org/10.3389/fpls.2017. 02013

[6] Niehaus EM., Kim HK., MuÈnsterkoÈtter M., Janevska S., Arndt B., SA. Kalinina et al., "Comparative genomics of geographically distant Fusarium fujikuroi isolates revealed two distinct pathotypes correlating with secondary metabolite profiles," PLoS Pathogen 13(10):e1006670. 2017. https://doi.org/10.1371/journal.ppat.1006670

[7] Anonymous, "IARI," Annual report 2017-18, Indian Agricultural Research Institute, New Delhi-110012, India. 2018.

[8] Ou SH., "Rice disease," 2nd edition. Commonwealth Mycological Institute, Kew, England. 380p. 1985.

[9] Ito S., J. Kimura, "Studies on the 'bakanae' disease of the rice plant," Report of the Hokkaia National Agricultural Experiment Station. 27: 1-95. 1931.

[10] Pavgi MS., J. Singh, "Bakanae and Foot rot of rice in Uuar Pradesh, India," Plant disease reporter. 48: 340-342. 1964.

[11] Kanjanasoon P., "Studies on the bakanac disease of rice in Thailand," Doc. Agric. Thesis. Tokyo University, Japan. 1965.

[12] BRRI., “Annual Internal Review," BRRI Regional Station. Cumilla (For July 2003-June 2004). Bangladesh Rice Research Institute, Gazipur. p. 22. 2004.

[13] Lee SB., Hur YJ., JH. Cho et al., "Molecular mapping of $q B K 1^{W D}$, a major QTL for bakanae disease resistance in rice," Rice 11:3. 2018. https://doi.org/10.1186/s12284-017-0197-7

[14] Talukdar MJ., "Major diseases of rice in East Pakistan and their control," Mimeographed paper. Division of Mycology and Plant Pathology. Agril. Res. Inst., Tejgoan, Dhaka, Bangladesh. 1968. 
[15] Miah SA., MQ.Zaman, "Studies on the reaction of high yielding dwarf rice to foot-rot and bakanae in Bangladesh," Bangladesh J. Bot. 2(2): 73-81. 1973.

[16] Hossain MS., Ali MA., Mia MAT., Islam MS. ZR. Moni, "Estimation of yield loss by Fusarium moniliforme caused bakanae disease of rice," Eco-friendly Agril. J. 6(3): 40-43. 2013.

[17] KRAC (Kinki-Chugok.'11 Regional Agricultural Committee), "Cooperative studies on control of bakanae. brown spot and damping-off rice plant," Report of the Chugoku National Agricultural Experiment Station. 6: 1-77. 1975.

[18] ISTA, 1996. International Rules for seed testing. Seed Science and Technol. 4(1)1-180.

[19] Latif MA., Mia MAT. MA. Hossain,'YYield loss, integrated management approaches and development of quick screening method of bakanae disease of rice in Bangladesh," Abstract, 2nd international rice congress, October $9-13$, 2006. New Delhi, India.

[20] Miah SA., Shahjahan AKM., Hossain MA., NR. Sharma," A survey of rice diseases in Bangladesh. Tropical pest management. 31(3): 208-213. 1985.

[21] Rathaiah Y., Das GR., K II U. Singh," Estimation of yield loss and chemical control of bakanac disease of rice," Regional Agricultural Research Station. Titabur 785630, India. Oryza. 28(4): 509-512. 1991.

[22] Siddique AM., AH. Mohammed," Chemical control of bakanae disease by seed treatment," Bangladesh Journal of Botany, 12(1): 1-5. 1983.

[23] Sarkar BB.,"Controlling bakanae (Bak) and foot rot disease with fungicide seed treatments," International Rice Research Newsletter. 11 (3): 18. 1986.
[24] Rohilla R., Singh US., RL. Singh," Uptake and translocation of carpropamid in rice (Oryza sativa L). Pest Management Science. Volume 57(3): 239-247. 2001.

[25] Nel B., Steinberg C., Labuschagne N., A. Viljoen," Evaluation of fungicides and sterilants for potential application in the management of Fusarium wilt of banana," Crop Protection, 26(4): 697-705. 2007.

[26] Halil S., G. Halim," Research Activities on Controlling Rice Bakanae and Foot Rot Disease (Fusarium moniliforme) in Turkey," Cahiers Options Méditerranéennes, vol. 8 :27-30. 1994.

[27] Khan JAI., Jamil FF. MA. Gill," Screening of rice varieties/lines against bakanae and bacterial leaf blight (BLB)," Pakistan Journal of Phytopathology. 12(1): 6-1 1. 2000 .

[28] Kitamura Y., "Studies on the control of bakanae disease of rice plant II. Effect of benomyl and thiophenate-methyl by spraying at the flowering stage of rice plant on the control of bakanae disease," Proceedings of the Kansai Plant Protection Society. 18:23-27. 1976.

[29] Sunani SK., Bashyal BM., Aggarwal R., G. Prakash," Conidial germination of Fusarium fujikuroi causing bakanae disease of rice. Environ Ecol 35(4):2790-2794. 2017.

[30] [30] Ochi A., Konishi H., Ando S., Sato K., Yokoyama K., S. Tsushima et al.," Management of bakanae and bacterial seedling blight diseases in nurseries by irradiating rice seeds with atmospheric plasma," Plant Pathol 66(1):67-76. 2016. https://doi.org/10.1111/ppa.12555

[31] Kumar P., Sunder S., Singh R., A. Kumar," Management of foot rot and bakanae of rice through fungicides. Indian Phytopath 69(2):124-127. 2016.

[32] Hossain KS., Mia MAT., MA, Bashar," Management of bakanae disease of rice," Bangladesh J. Bot. 44(2):277-283, 2015 (June). 2015. DOI: 10.3329/bjb.v44i2.38517 